\title{
E-Learning in Universities and Its Application
}

\author{
Luay Abdulwahid Shihab
}

Department of Branch of Basic Science, College of Nursing, University of Basrah, Basrah, Iraq

DOI: $10.36347 /$ sjet.2020.v08i04.005

| Received: 04.04.2020 | Accepted: 11.04.2020 | Published: 28.04.2020

*Corresponding author: Luay Abdulwahid Shihab

Abstract

The aim of the study is to identify the negatives in e-learning in universities and their application and how to treat through current health conditions and how to communicate and clarify electronic and video lectures and conduct electronic tests.

Keywords: Reality, e-learning, application.

Copyright @ 2020: This is an open-access article distributed under the terms of the Creative Commons Attribution license which permits unrestricted use, distribution, and reproduction in any medium for non-commercial use (NonCommercial, or CC-BY-NC) provided the original author and source are credited.

\section{INTRODUCTION}

E-learning is an interactive learning that provides relevant learning content online and provides an environment for student learning activities.

E-learning covers applications and processes, such as web-based learning, blog-based learning, computer-based learning, virtual classes, and digital collaboration.

It includes delivery of subject content via the Internet, intranet / extranet, satellite broadcasting, interactive TV, CD-ROM, DVD, audio, videotape [1].

One of the most important obstacles is the lack of a full staff of e-learning employees, and students find it difficult to use the English language when using elearning.

E-learning can be described as educational content for the subject or learning experiences provided or enabled by electronic technology [2]. it is an organized and interactive way to teach students or inform students and teachers, when you're a student program of teacher the student to enter his name and number, and after that the number of students connected is equal to the number of students who admitted their names and their numbers, he moves the teacher to the page (the teacher), where the teacher has to enter his name and the word password after that choose the teacher name from the list and write the password for showing a group of fields that must be filled out and after filling the fields show a series of questions introduced by the teacher through the program (introduction of questions) so that he can choose the question that he wants the teacher sent to the students and after that chose the teacher question is sent to students callers where they are moving to a page (responses) If you do not need the student to the question mark appears (error (if the student replied, an answer true mark appears (true) and if the student replied, wrong answer mark appears (error (and when he wants Prof. look at the results of students or print the results, it must go to the page (the reports) to print the report to a file (Excel) report on paper [3].

\section{The importance of e-learning}

It is not to send an electronic lecture and drop the teacher's hypothesis from students, it is an online education and not just a transfer of information online It is online education, not just online information transfer People have different perspectives regarding e-learning, the specific need is closely related to the approach to elearning policy. The speed and magnitude of the educational disorder as a result of the spread of the Coruna virus - which now affects 200 million students worldwide - is negligible in recent history. Therefore, the closure of universities for several days, weeks and sometimes even months may have repercussions, and therefore it has become necessary to discuss the need for e-learning. In many subjects, the shortage of qualified teachers is the problem that educational institutions face.

\section{E-learning application}

When applying e-learning, especially in our current circumstances, there must be a link between students and the teacher, and all students must interact with the provision of the Internet to all students so that there is no obstacle as for learning and learner and in 
our time many platforms have been launched where the student and the teacher have many facilities Also, there are many centers of e-learning, coordinators and trainers so that the barrier between students is broken to provide an e-learning environment.

\section{RECOMMENDATIONS}

First, to provide a high-quality network with a capacity of 200 megabytes, to provide a high-speed delivery, download electronic and video lectures, and exchange data and exams in the case of interactive education.

Second, providing high-speed capacity servers, and peripherals

Third, an Internet must be provided to all students in order to communicate in the best way.
Fourth, ensuring the quality of teacher education on e-learning

Fifth, Providing students with explanatory and interactive courses about the work of e-learning and establishing continuous practical tests to facilitate the work

\section{REFERENCES}

1. A.M. Dr. Mona Hadi Saleh, Study and Download Technologies of Electronic Circular, Al-Ustaz Magazine. 502(5002): 0121.

2. Dr. Ibrahim Ibrahim Muhammad Abu Aqil, The reality of e-learning and its obstacles in using university education from the viewpoint of Hebron University students, Palestine University Journal for Research and Studies. 2014; 7.

3. Luaay abdulwahed and Hisham ahmed program of computerized examination International Journal of Current Research.2012; 4(01), 096-099. 